Technological University Dublin ARROW@TU Dublin

\title{
Spirobicyclic Diamines. Part 3: Synthesis and Metal Complexation of Proline-Derived [4,4]-Spirodiamines.
}

\author{
Fintan Kelleher \\ Technological University Dublin, fintan.kelleher@tudublin.ie \\ Sinead Kelly \\ Technological University Dublin \\ Vickie McKee \\ Loughborough University
}

Follow this and additional works at: https://arrow.tudublin.ie/ittsciart

\section{Recommended Citation \\ Kelleher, F., Kelly, S,. McKee, V., : Spirobicyclic Diamines. Part 3: Synthesis and Metal Complexation of Proline-Derived [4,4]-Spirodiamines. Tetrahedron, Vol. 63 (37) 10th Septemner, 2007, pp. 9235-9242, DOI : 10.1016/j.tet. 2007.06.050}

This Article is brought to you for free and open access by the School of Science and Computing at ARROW@TU Dublin. It has been accepted for inclusion in Articles by an authorized administrator of ARROW@TU Dublin. For more information, please contact arrow.admin@tudublin.ie, aisling.coyne@tudublin.ie, gerard.connolly@tudublin.ie. Funder: Irish Government

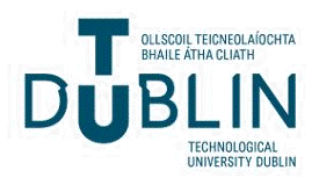


Spirobicyclic diamines. Part 3: Synthesis and metal complexation of prolinederived $[4,4]$-spirodiamines.

Fintan Kelleher, ${ }^{\mathrm{a}, \mathrm{b}}$ Sinead Kelly ${ }^{\mathrm{a}}$ and Vickie $\mathrm{McKee}^{\mathrm{c}}$

${ }^{\text {a }}$ Department of Science and Advanced Smart Materials Centre, Institute of Technology Tallaght, Dublin 24, Ireland.

${ }^{b}$ National Institute for Cellular Biotechnology, Institute of Technology Tallaght,

Dublin 24, Ireland.

${ }^{c}$ Chemistry Department, Loughborough University, Loughborough, Leics. LE11 3TU, $U K$.

Corresponding Author: Dr. Fintan Kelleher

Address: $\quad$ Department of Science,

Institute of Technology Tallaght,

Tallaght,

Dublin 24,

Ireland.

Phone Number: ～（+353 1) 4042869

Fax Number: $\quad$ (+353 1) 4042700

e-mail address: $\quad$ fintan.kelleher@ittdublin.ie

Graphical abstract :

Spirobicyclic diamines. Part 3: Synthesis and metal complexation of proline-derived $[4,4]-$ spirodiamines.

Fintan Kelleher,* Sinead Kelly and Vickie McKee.

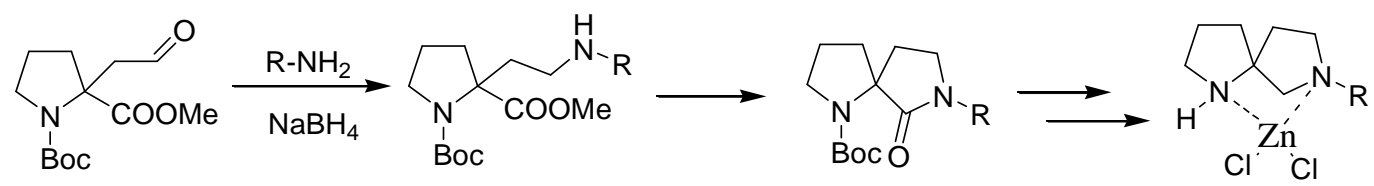




\title{
Spirobicyclic diamines. Part 3: Synthesis and metal complexation of proline- derived $[4,4]$-spirodiamines.
}

Fintan Kelleher* $^{\text {a,b }}$, Sinead Kelly ${ }^{\mathrm{a}}$ and Vickie McKee ${ }^{\mathrm{c}}$

${ }^{a}$ Department of Science and Advanced Smart Materials Centre, Institute of Technology Tallaght, Dublin 24, Ireland.

${ }^{b}$ National Institute for Cellular Biotechnology, Institute of Technology Tallaght,

Dublin 24, Ireland.

${ }^{c}$ Chemistry Department, Loughborough University, Loughborough, Leics. LE11 3TU, $U K$.

\begin{abstract}
The syntheses of racemic and homochiral [4.4]-spirolactams, starting from L-proline, in good yields are described. Reduction of the lactam carbonyl group of spirolactams, containing chiral substituents on the lactam nitrogen, with lithium aluminium hydride, gives a series of homochiral [4.4]-spirodiamines. The crystal structure of one of these spirodiamines on complexation with zinc chloride was obtained. Interestingly it showed a hydrogen-bonded dimeric structure, where the monomers are diastereoisomeric diamines.
\end{abstract}

\section{Keywords}

Spirolactam; Spirodiamines; Synthesis; X-ray crystal structure; Dimer.

\section{Introduction}

Diamines, especially vicinal diamines, are of interest because of their ability to strongly bind metal ions leading to Lewis acid complexes, which have found uses as catalysts in a wide range of organic syntheses. ${ }^{1}$ Many of the well known diamines, such as ethylenediamine (1, Figure 1), are acyclic and are very flexible in nature. The introduction of constraints into such structures is a well studied method for reducing 
this conformational flexibility giving molecules with a more defined 3-D structure [e.g., trans-1,2-diaminocyclohexane $(2)^{2}$ is a constrained version of ethylenediamine]. In some cases this has been used in biologically active molecules to either increase the affinity of the molecule for its target (cyclic versus acyclic peptides), ${ }^{3}$ or to make the molecules more metabolically stable, which can lead to improved bioavailability. ${ }^{4}$ The naturally occurring polycyclic diamine (-)-sparteine (3) has found use as a chiral ligand in a number of applications in asymmetric synthesis. ${ }^{5}$ Another method of constraint which has been used is to introduce a spiro fusion of two rings which forces the nitrogen atoms into a mutually orthogonal relationship (4, Figure 1).

There are currently a large number of methods for the synthesis of spirocyclic compounds and they can also be easily formed in a stereocontrolled manner. ${ }^{6}$ Freidinger was the first to incorporate a lactam constraint in the backbone of a peptide in order to rigidify the peptide tertiary structure into a more defined conformation. ${ }^{7}$ One of the most common methods for the synthesis of lactams is the cyclisation of an amino group (primary or secondary) onto a carboxylic ester, with concomitant loss of an alcohol. The overall efficiency of the cyclisation is dependent on the size of the ring being formed, the nature of the amino substitutent in the case of a secondary amine, any substituents on the resulting ring and the structure of the alkyl moiety of the ester group. Many of the reactions take place spontaneously at ambient temperature, while others require heating in a suitable solvent. ${ }^{8}$

L-Proline-derived spirolactams have in particular been studied for their use in constraining peptides with L-proline residues to mimic the $\beta$-turn, a very important component of peptide secondary structure. Depending on their final use spirolactams are synthesised either as racemic mixtures or as single enantiomers. In most cases these syntheses start from L-proline which must then be alkylated in the $\alpha$-position. Full control of the stereochemistry can easily be achieved using Seebach's "SelfReproduction of Chirality" methodology, ${ }^{9}$ whereas the racemic compounds simply require alkylation of the enolate of a suitably protected proline molecule which, after a series of further functional group manipulations, gives cyclisation precursors.

A number of different strategies have also been used for the critical final cyclisation step to form the spirobicyclic lactam ring. These include (i) intramolecular amide 
coupling, with a coupling agent (e.g. DCC or EDC), of tethered secondary amines with the deprotected proline carboxylic acid group; ${ }^{10}$ (ii) cyclisation of proline carboxylic amides onto a primary alcohol under Mitsunobu conditions; ${ }^{11}$ and (iii) thermal cyclisation of a tethered secondary amine onto a proline carboxylic ester in DMF at $70{ }^{\circ} \mathrm{C}$, although the yield of the latter reaction was very low (27\%), with only one diastereoisomer cyclising and the side chain carboxylic acid subsequently being converted to the methyl ester by treatment with diazomethane (Figure 2). ${ }^{12}$

\section{Results and Discussion}

As part of a programme of research to synthesise both racemic and homochiral spirocycles, the synthesis of proline-derived [4.4]-spirolactams ${ }^{13,15}$ and their conversion to spirodiamines was of interest.

The variety of different cyclisation methods used, along with their wide ranging yields, prompted us to study one of the methods, the thermal cyclisation reaction, in more detail in order to investigate whether it was a viable method for the synthesis of a range of proline-derived [4.4]-spirolactams. This necessitated the synthesis of secondary amines for subsequent cyclisation onto a carboxylic ester (Scheme 1). ${ }^{13}$

The required secondary amines (9a-c) would be obtained by reductive amination of the racemic aldehyde $\mathbf{8}$, so the efficient synthesis of this aldehyde was critical to the overall success of this method, as a generalised route to spirolactams. 8 was prepared in 4 steps from L-proline by Boc protection of the nitrogen of the methyl ester of Lproline, which was obtained quantitatively from L-proline by treatment with $\mathrm{SOCl}_{2}$ in methanol. The $\alpha$-allyl group was efficiently introduced in $80 \%$ yield. ${ }^{14}$ Oxidative cleavage of the alkene using $\mathrm{OsO}_{4} / \mathrm{NaIO}_{4}$ gave the aldehyde 8 in a $74 \%$ yield. ${ }^{10 \mathrm{e}}$ It was necessary to efficiently purify the aldehyde by column chromatography to free it from any traces of osmium by-products, as failure to do so led to major reductions in the yield of the subsequent reductive amination and cyclisation reactions, with a large amount of decomposition occurring. Reductive amination of $\mathbf{8}$ with allyl amine, gave the required secondary amine spirolactam precursor 9a. Following the method of Johnson ${ }^{11 \mathrm{a}}$, thermal cyclcisation of $9 \mathbf{a}$ in DMF at $70{ }^{\circ} \mathrm{C}$ gave the spirolactam 10a in a 
$99 \%$ yield, though the work-up was lengthy. Cyclisation in refluxing toluene gave 10a in a $66 \%$ yield, with a simpler work-up procedure. When benzylamine was used in place of allyl amine, using the same reaction cyclisation conditions, the $\mathrm{N}$-benzyl substituted spirolactam (10a) was obtained in a higher yield of $75 \%$.

Extension of this methodology using chiral $\alpha$-substituted amines would give pairs of diastereoisomeric spirolactams. ${ }^{15}$ Reductive amination of aldehyde 8 with either $(R)$ or $(S)$ - $\alpha$-methylbenzylamine gave spirolactams 11a \& 11b (Scheme 2). Prolonged stirring of solutions of these compounds in refluxing toluene gave no indication of any cyclisation. In a similar cyclisation reaction of a secondary amine, where alanine methyl ester was used in the reductive amination step, Auberson et al. were able to successfully achieve cyclisation in yields of $>90 \%$, by stirring at reflux temperature in xylenes for 2 hours. ${ }^{16}$ Stirring solutions of amino esters 11a or 11b in refluxing xylenes, even for extended periods of time, gave no indication of any cyclisation reaction occurring.

Treatment of toluene solutions of $\mathbf{1 1 a}$ or $\mathbf{1 1 b}$ with sodium amide (50\% solution in toluene) at reflux temperature gave the desired spirolactams 12a-d (as pairs of diastereoisomers in 1:1 ratios), isolated in yields of $30 \%$ and $51 \%$, from aldehyde 8. HPLC analysis of each diastereoisomer showed a high degree of purity (all greater than $98.8 \%$ pure). The only impurity identified, in each case, was the diastereoisomeric product produced in the reaction.

It was not possible to obtain crystals suitable for X-ray analysis of any of the four diastereoisomers 12a-d. Although the stereochemistry of the $\alpha$-methyl benzyl substituent was known from the choice of the starting homochiral amine the absolute stereochemistry of the spiro centre in each case was not. Molecular modelling ${ }^{17}$ was used to give minimised energy conformations of the $S R$ and $R R$ diastereoisomeric pair (12a \& 12b). It was immediately evident from the minimised structures (Figure 3) that in the $S R$ diastereoisomer the hydrogens of the Boc protecting group and the meta hydrogens of the phenyl group were close in space (closest distance of $2.67 \AA$ ), whereas in the $R R$ isomer the Boc and phenyl groups were a large distance apart. It was therefore expected that NOE NMR experiments would be able to distinguish 
between the two diastereoisomers. Irradiation of the signal for the hydrogens of the Boc group of the diastereoisomer assigned as $S R$ showed an NOE to the phenyl hydrogens, whilst no similar NOE was observed in the case of the $R R$ diastereoisomer, though this is not conclusive proof of the absolute stereochemistry of the spiro centre.

The homochiral diamines derived from the spirolactams 12a-d were obtained when the $N$-Boc protecting group was cleanly removed from each spirolactam to give the free amino spirolactams 13a-d, and the reduction of the lactams was then examined. The optimal conditions found for successful reduction was the use of 20 molar equivalents of lithium aluminium hydride in THF (Scheme 3), which gave the diamines 14a-d in acceptable isolated yields (43-56\%).

One of our interests is in the use of these diamines as ligands for metal ions, thus giving chiral complexes which may have potential as novel chiral catalysts in asymmetric transformations. The first step was to examine whether the amines bound to a metal ion. No complexation was observed when ethanolic solutions of the amines were treated with copper(II) acetate. Zinc(II) was then chosen as it is diamagnetic, making studies of complexation also possible by NMR spectroscopy. When ethanolic solutions of amines 14a-d were refluxed with 1.5 molar equivalents of $\mathrm{ZnCl}_{2}$ and the solutions were left standing at room temperature, the solutions containing amines 14a and 14b each gave one small single crystal (15a and 15b) suitable for X-ray analysis. The surprise result from these studies was that the X-ray crystal structures of the zinc complexes 15a and $\mathbf{1 5 b}$ were identical (Figure 3).

Close examination of the X-ray structures shows that a 1:1 dimeric complex had formed where each spirodiamine accommodates one zinc metal. The asymmetric unit of the crystal contains two independent molecules linked into a hydrogen-bonded dimer. Each zinc atom occupies a pseudo-tetrahedral geometry, where it is complexed to the two nitrogens of the spirocycle and to two chlorine atoms. The $\mathrm{N}-\mathrm{Zn}-\mathrm{N}$ angle is $84.4(2)^{\circ}$ in both molecules of the dimer, and the $\mathrm{Cl}-\mathrm{Zn}-\mathrm{Cl}$ angle is $120.71(7)^{\circ}$ in one molecule while it is $119.11(7)^{\circ}$ in the other. The dimer is then formed by two intermolecular hydrogen bonds via one of the chlorine atoms and an amine N-H. The nitrogen to chlorine distances for the two hydrogen bonds are 3.355(6) and 3.372(6) 
$\AA$. The important bond lengths and angles are shown in Table 1. The formation of a dimer may not in itself unusual, but the most intriguing aspect of the crystal structure is that the two spirodiamines that make up the dimer are diastereoisomeric. This result was certainly not anticipated as purification of each precursor amine (14a-d) was carried out very carefully. HPLC analysis showed that there was only a very small amount of the corresponding disatereoisomer present in the "purified" amines. In the case of $14 \mathbf{a}$ it was shown to be $98.7 \%$ pure with $1.2 \%$ of $\mathbf{1 4 b}$ being present. Therefore on complexation with zinc chloride the vast majority of complexed diamine 14a remained in solution with only a small amount crystallising out with the opposite diastereoisomeric diamine "impurity" 14b. Also by HPLC analysis amine 14b was found to be $99.3 \%$ pure, contaminated with only $0.7 \%$ of the diasteresoisomer $\mathbf{1 4 a}$. Again on complexation with zinc chloride the same result was obtained as before.

Thus the ability of the chiral spirodiamines to complex a selected metal ion has been demonstrated. Mukaiyama has studied the asymmetric catalysis of the aldol reaction (Mukaiyama aldol) using diamines derived from L-proline, which are complexed to tin(II) triflate, as asymmetric catalysts (Figure 4). ${ }^{18}$ Using molecular modelling, ${ }^{17}$ when the proline-derived diamine $\mathbf{1 6}$ was bound to zinc chloride and was minimised, the $N-N$ distance was calculated to be $2.77 \AA$. From the crystal structure of complex 15a it is observed that the $N-N$ distances are $2.797 \AA$ and $2.798 \AA$. Thus these distances compare very favourably with the calculated value for the Mukaiyama ligand 16, above. This leads us to believe that the spirodiamines 14a-d have the potential to be used as ligands for $\mathrm{Sn}^{2+}$, with the resulting complexes being used as catalysts in the asymmetric Mukaiyama aldol reaction. It is also envisaged that the spirodiamines will complex other metal ions, and thus have applications in metal catalysed asymmetric synthetic reactions. It is also envisaged that the homochiral spirolactams 13a-d will have applications as novel organocatalysts. All of these studies are currently being undertaken.

\section{Conclusions.}

In conclusion, a series of homochiral spirolactams derived from L-proline have been prepared. These spirolactams were reduced to spirodiamines using lithium aluminium hydride as reductant, and the diamines formed complexes with zinc chloride. The X- 
ray crystal structure of one of these complexes showed an unusual dimeric form where the two spirodiamines present were diastereoisomeric. The properties of these spirodiamines are currently being further elucidated and their potential as ligands for metals to act as catalysts in asymmetric synthesis is currently being undertaken. The results of these studies will be reported in due course.

\section{Experimental.}

Allyl bromide was purified by passing it through a plug of activity III basic alumina. TLC was performed on Merck silica gel $60 \mathrm{~F}_{254}$ plates and column chromatography was performed on Aldrich silica gel, $70-230$ mesh, $60 \AA .{ }^{1} \mathrm{H}$ and ${ }^{13} \mathrm{C} \mathrm{NMR}(\delta \mathrm{ppm} ; J$ $\mathrm{Hz}$ ) spectra were recorded on a Jeol JNM-LA300 FT-NMR spectrometer using $\mathrm{CDCl}_{3}$ solutions with $\mathrm{Me}_{4} \mathrm{Si}$ as internal reference, unless otherwise indicated, with resolutions of $0.18 \mathrm{~Hz}$ and $0.01 \mathrm{ppm}$, respectively. $\mathrm{CHCl}_{3}$ was used to remove last traces of ethyl acetate from some samples. The last trace of $\mathrm{CHCl}_{3}$ persisted even after prolonged heating in vacuo and in these cases was visible in NMR spectra and microanalysis. Infrared spectra $\left(\mathrm{cm}^{-1}\right)$ were recorded as $\mathrm{KBr}$ discs or liquid films between $\mathrm{NaCl}$ plates using a Nicolet Impact 410 FT-IR. Melting points were obtained on a Bibby Stuart Scientific SMP1 melting point apparatus and are uncorrected. Microanalyses were carried out at the Microanalytical Laboratory of University College Dublin. Mass spectra were obtained in the Centre for Synthesis and Chemical Biology, School of Chemistry and Chemical Biology, University College Dublin. Xray crystal structures were obtained in the Chemistry Department, Loughborough University, Loughborough, UK. HPLC analysis were carried out using methods on a Shimadzu HPLC system Class-VP, incorporating a LC-10AD pump, SPD-M10AVP Diode Array Detector, Auto-injector SIJ-10A with a system controller SCL-10A VP. Polarimetry was carried out at Dublin City University (DCU), using a Perkin-Elmer 343 with cell path-length of $100 \mathrm{~mm}$ at $20^{\circ} \mathrm{C}$.

\section{$N$-Boc-L-proline methyl ester (6). ${ }^{14}$}

6 was prepared from L-proline by the method of Confalone. ${ }^{14}$ Microanalysis: Found C, 57.51; H, 8.60; N, 5.88. Calculated for $\mathrm{C}_{11} \mathrm{H}_{19} \mathrm{NO}_{4}$ : C, 57.60; H, 8.34; N, 6.10. 


\section{$( \pm)-\alpha$-Allyl $N$-Boc-proline methyl ester (7). ${ }^{14}$}

7 was prepared from 6 by the method of Confalone, ${ }^{14}$ except a $1 \mathrm{M}$ solution of LiHMDS in tetrahydrofuran, instead of hexane, was used as the base. Microanalysis: Found C, 62.29; H, 8.80; N, 4.95. Calculated for $\mathrm{C}_{14} \mathrm{H}_{23} \mathrm{NO}_{4}$ : C, 62.43; H, 8.61; N, 5.20 .

$( \pm)$ - $\alpha$-Formylmethyl $N$-Boc-proline methyl ester $(8) .{ }^{10 \mathrm{e}}$

8 was prepared from 7 by the method of Johnson. ${ }^{10 \mathrm{e}}$ Microanalysis: Found C, 53.59; $\mathrm{H}, 7.60 ; \mathrm{N}, 4.22$. Calculated for $\mathrm{C}_{14} \mathrm{H}_{23} \mathrm{NO}_{4}\left(0.33 \mathrm{CHCl}_{3}\right)$ : C, 53.43; H, 7.40; N, 4.67.

\section{(士)-7-Allyl-6-oxo-1,7-diazaspiro[4.4]nonane-1-carboxylic acid tert-butyl ester} (10a) Method A: To a stirred solution of $8(0.10 \mathrm{~g}, 0.35 \mathrm{mmol})$ in ethanol $(3 \mathrm{ml})$ under nitrogen, was added dropwise allyl amine $(0.030 \mathrm{ml}, 0.35 \mathrm{mmol})$, over $10 \mathrm{~min}$ at ambient temperature, and the solution was stirred for $2 \mathrm{~h}$. Sodium borohydride (0.020 g, $0.42 \mathrm{mmol})$ was added in small portions over $5 \mathrm{~min}$ and the resulting solution was stirred at ambient temperature for $48 \mathrm{~h}$. Water $(30 \mathrm{ml})$ was added and the mixture was extracted with ethyl acetate $(3 \times 15 \mathrm{ml}$ ), and the combined organic layers were washed with brine $(2 \times 15 \mathrm{ml})$, dried over $\mathrm{MgSO}_{4}$ and concentrated in vacuo. The residue was dissolved in DMF $(5 \mathrm{ml})$ under nitrogen, to which triethylamine $(0.050 \mathrm{ml}, 0.35 \mathrm{mmol})$ was added. The solution was stirred at $70{ }^{\circ} \mathrm{C}$ for $24 \mathrm{~h}$, poured into water $(50 \mathrm{ml})$ and extracted with ethyl acetate $(3 \times 20 \mathrm{ml})$. The combined organic layers were washed with $10 \%$ citric acid solution $(2 \times 20 \mathrm{ml})$, water $(4 \times 20 \mathrm{ml})$, brine $\left(2 \times 20 \mathrm{ml}\right.$ ), dried over $\mathrm{MgSO}_{4}$ and concentrated in vacuo giving 10a as an oil $(0.092 \mathrm{~g}, 99 \%)$. $\mathrm{R}_{\mathrm{f}} 0.21,40 \%$ ethyl acetate/hexane. IR (thin film) $/ \mathrm{cm}^{-1} 2986,1682$, 1388, 901. ${ }^{1} \mathrm{H}$ NMR (two rotamers present) $\delta$ 5.81-5.66 (m, 1H, olefin $\mathrm{CH}$ ), 5.26-5.16 (m, 2H, olefin $\left.\mathrm{CH}_{2}\right), 4.13-4.01\left(\mathrm{~m}, 1 \mathrm{H}\right.$, allyl $\left.\mathrm{CH}_{2}\right), 3.85-3.67\left(\mathrm{~m}, 1 \mathrm{H}\right.$, allyl $\left.\mathrm{CH}_{2}\right)$, 3.573.47 (m, 2H, pyrrolidine $\left.\alpha-\mathrm{CH}_{2}\right), 3.41-3.14\left(\mathrm{~m}, 2 \mathrm{H}\right.$, lactam $\left.\gamma-\mathrm{CH}_{2}\right), 2.70-2.41(\mathrm{~m}, 2 \mathrm{H}$, lactam $\beta-\mathrm{CH}_{2}$ ), 2.12-1.80 (m, $4 \mathrm{H}$, pyrrolidine $\beta$ - and $\left.\gamma-\mathrm{CH}_{2}\right), 1.44$ and $1.42(2 \mathrm{x} \mathrm{s}$, 9H, $t$-butyl). ${ }^{13} \mathrm{C}$ NMR $\delta 174.24$ and 174.20 (lactam carbonyl), 154.0 and 153.6 (Boc carbonyl), 136.6 and 136.2 (olefin $\mathrm{CH}$ ), 118.6, 117.9 (olefin $\mathrm{CH}_{2}$ ), 80.0 and 79.5 ( $t$ butyl $\mathrm{C}_{\mathrm{q}}$ ), 67.0 and 66.7 (spiro $\mathrm{C}_{\mathrm{q}}$ ), 48.0 and 47.7 (allyl $\mathrm{CH}_{2}$ ), 46.1 (pyrrolidine $\delta$ $\mathrm{CH}_{2}$ ), 43.1 and 42.7 (lactam $\gamma-\mathrm{CH}_{2}$ ), 37.6 and 37.1 (lactam $\beta-\mathrm{CH}_{2}$ ), 31.0 and 30.2 (pyrrolidine $\beta-\mathrm{CH}_{2}$ ), 28.6 (t-butyl $\mathrm{CH}_{3}$ ), 23.4 and 22.7 (pyrrolidine $\gamma-\mathrm{CH}_{2}$ ). 
Microanalysis: Found C, 57.81; H, 7.98; N, 8.60. Calculated for $\mathrm{C}_{15} \mathrm{H}_{24} \mathrm{~N}_{2} \mathrm{O}_{3}(0.5$ $\left.\mathrm{CHCl}_{3}\right): \mathrm{C}, 57.76 ; \mathrm{H}, 7.66 ; \mathrm{N}, 8.69$.

Method B: To a stirred solution of allylamine $(0.37 \mathrm{ml}, 4.9 \mathrm{mmol})$ in dry methanol (7 $\mathrm{ml})$ was added a solution of $\mathbf{8}(1.20 \mathrm{~g}, 4.4 \mathrm{mmol})$ in dry methanol $(1.5 \mathrm{ml})$. Magnesium sulphate $(0.316 \mathrm{~g}, 2.6 \mathrm{mmol})$ was added to the solution after $3 \mathrm{~h}$ and the solution was then stirred for a further $2 \mathrm{~h}$. The reaction was cooled to $-4{ }^{\circ} \mathrm{C}$ and $\mathrm{NaBH}_{4}(0.294 \mathrm{~g}, 7.8 \mathrm{mmol})$ was added portionwise. The reaction was quenched after $1 \mathrm{~h}$ with a saturated solution of $\mathrm{NaHCO}_{3}(5 \mathrm{ml})$ and water $(5 \mathrm{ml})$. The mixture was extracted with ethyl acetate $(3 \times 30 \mathrm{ml})$ then dried over $\mathrm{MgSO}_{4}$ and concentrated in vасио. The resulting oil was stirred at reflux temperature in toluene $(15 \mathrm{ml})$ for $16 \mathrm{~h}$. After cooling to ambient temperature the solution was concentrated in vacuo giving an oil which was purified on silica gel in $10 \%$ ethyl acetate/hexane to give a pale yellow oil (0.685 g, 60\%). For analysis see Method A.

\section{(士)-7-Benzyl-6-oxo-1,7-diazaspiro[4.4]nonane-1-carboxylic acid tert-butyl ester}

(10b) Method A: Prepared by a similar method to 10a (method A) using benzylamine giving a pale yellow oil ( $88 \%$ yield). $\mathrm{R}_{\mathrm{f}} 0.12,40 \%$ ethyl acetate/hexane. IR (thin film) $/ \mathrm{cm}^{-1}: 3000,2950,1700,1680 .{ }^{1} \mathrm{H}$ NMR (two rotamers present) $\delta$ 7.35-7.22 (m, 5H, aromatic), $4.90\left(\mathrm{~d}, 1 \mathrm{H}, J=14.7 \mathrm{~Hz}\right.$, benzyl $\left.\mathrm{CH}_{2}\right), 4.72(\mathrm{~d}, 1 \mathrm{H}, J=14.4 \mathrm{~Hz}$, benzyl $\left.\mathrm{CH}_{2}\right), 4.28\left(\mathrm{~d}, 1 \mathrm{H}, J=15 \mathrm{~Hz}\right.$, benzyl $\left.\mathrm{CH}_{2}\right), 3.97(\mathrm{~d}, 1 \mathrm{H}, J=14.5 \mathrm{~Hz}$, benzyl $\mathrm{CH}_{2}$ ), 3.62-3.42 (m, 2H, pyrrolidine $\left.\alpha-\mathrm{CH}_{2}\right), 3.34-3.03\left(\mathrm{~m}, 2 \mathrm{H}\right.$, lactam $\left.\gamma-\mathrm{CH}_{2}\right)$, 2.66$2.39\left(\mathrm{~m}, 1 \mathrm{H}\right.$, lactam $\left.\beta-\mathrm{CH}_{2}\right), 2.21-2.08\left(\mathrm{~m}, 1 \mathrm{H}\right.$, lactam $\left.\beta-\mathrm{CH}_{2}\right), 2.06-1.95(\mathrm{~m}, 2 \mathrm{H}$, pyrrolidine $\left.\beta-\mathrm{CH}_{2}\right), 1.89-1.76\left(\mathrm{~m}, 2 \mathrm{H}\right.$, pyrrolidine $\left.\gamma-\mathrm{CH}_{2}\right), 1.46$ and $1.39(2 \mathrm{x} \mathrm{s}, 9 \mathrm{H}, t$ butyl). ${ }^{13} \mathrm{C}$ NMR (two rotamers present) $\delta 174.5$ and 174.4 (lactam carbonyl), 153.5 and 153.4 (Boc carbonyl), 136.6 (ipso aromatic), 128.7, 128.4 and 128.3 (aromatic $\mathrm{CH}$ ), 80.0 and 79.5 ( $t$-butyl $\mathrm{C}_{\mathrm{q}}$ ), 67.0 and 66.9 (spiro $\mathrm{C}_{\mathrm{q}}$ ), 48.0 and 47.8 (benzyl $\mathrm{CH}_{2}$ ), 47.5 and 47.4 (lactam $\gamma-\mathrm{CH}_{2}$ ), 42.9 and 42.7 (pyrrolidine $\delta-\mathrm{CH}_{2}$ ), 37.8 and 37.1 (lactam $\beta-\mathrm{CH}_{2}$ ), 30.9 and 30.8 (pyrrolidine $\beta-\mathrm{CH}_{2}$ ), 28.5 ( $t$-butyl $\mathrm{CH}_{3}$ ), 23.4 and 22.8 (pyrrolidine $\gamma-\mathrm{CH}_{2}$ ). Microanalysis: Found C, 62.55; H, 7.39; N, 7.14. Calculated for $\mathrm{C}_{15} \mathrm{H}_{24} \mathrm{~N}_{2} \mathrm{O}_{3}\left(0.5 \mathrm{CHCl}_{3}\right): \mathrm{C}, 62.73 ; \mathrm{H}, 7.42 ; \mathrm{N}, 7.50$. 
Method B: 10b was prepared by a similar method to that used for 10a (Method B) giving a pale yellow oil $(1.46 \mathrm{~g}, 75 \%)$ after purification on silica gel in $15 \%$ ethyl acetate/hexane. For analysis see method A.

$(5 S)$

and

(5R)-6-Oxo-7-((1'R)-phenylethyl-)-1,7-diaza-spiro[4.4]nonane-1carboxylic acid tert-butyl ester (12a and 12b).

To a stirred solution of $(R)-(+)-1$-phenylethyl amine $(1.29 \mathrm{ml}, 10.1 \mathrm{mmol})$ in dry methanol $(6 \mathrm{ml})$ was added a solution of aldehyde $8(2.5 \mathrm{~g}, 9.22 \mathrm{mmol})$ in dry methanol $(2 \mathrm{ml})$. After $1 \mathrm{~h}$ of stirring at ambient temperature, magnesium sulphate ( $0.66 \mathrm{~g}, 5.5 \mathrm{mmol})$ was added to the solution and stirring was continued for $4 \mathrm{~h}$. The reaction was cooled to $-4{ }^{\circ} \mathrm{C}$ and $\mathrm{NaBH}_{4}(0.56 \mathrm{~g}, 15 \mathrm{mmol})$ was added portionwise over $10 \mathrm{~min}$. The reaction was quenched after $1 \mathrm{~h}$ at ambient temperature with a saturated solution of $\mathrm{NaHCO}_{3}(7 \mathrm{ml})$ and water $(3 \mathrm{ml})$. The aqueous layer was extracted with ethyl acetate $(3 \times 30 \mathrm{ml})$, dried over $\mathrm{MgSO}_{4}$ and concentrated in vacuo to give a yellow oil $(2.10 \mathrm{~g})$. The resulting oil was stirred at reflux temperature for 24 $\mathrm{h}$ in toluene $(20 \mathrm{ml})$ in the presence of $50 \%$ sodium amide (suspension) in toluene $(0.20 \mathrm{ml}, 5.2 \mathrm{mmol})$. After cooling to ambient temperature the solution was quenched with $\mathrm{H}_{2} \mathrm{O}(4 \mathrm{ml})$, and extracted with ethyl acetate (3 x 20ml). The combined organics were then concentrated in vacuo to give a colourless oil $(0.909 \mathrm{~g}, 30 \%)$, which was purified by flash column chromatography on silica gel in $10 \%$ ethyl acetate/hexane resulting in 12a $(0.491 \mathrm{~g}, 54 \%)$ as a white solid. $\mathrm{R}_{\mathrm{f}} 0.78$ (60\% ethyl acetate/hexane). Mp 92-96 ${ }^{\circ} \mathrm{C}$. IR (KBr) $/ \mathrm{cm}^{-1}$ 3031, 2976, 1702, 1682, 1361. ${ }^{1} \mathrm{H}$ NMR (two rotamers present) $\delta 7.35-7.25(\mathrm{~m}, 5 \mathrm{H}$, aromatic), 5.77-5.49 (m, $1 \mathrm{H}, \alpha-\mathrm{CH}), 3.58-3.44(\mathrm{~m}, 2 \mathrm{H}$, pyrrolidine $\left.\alpha-\mathrm{CH}_{2}\right), 3.42-3.23\left(\mathrm{~m}, 1 \mathrm{H}\right.$, lactam $\left.\gamma-\mathrm{CH}_{2}\right), 2.79-2.67(\mathrm{~m}, 1 \mathrm{H}$, lactam $\gamma-$ $\left.\mathrm{CH}_{2}\right), 2.61-2.37\left(\mathrm{~m}, 1 \mathrm{H}\right.$, lactam $\left.\beta-\mathrm{CH}_{2}\right), 2.13-1.66\left(\mathrm{~m}, 5 \mathrm{H}\right.$, pyrrolidine $\beta$ - and $\gamma-\mathrm{CH}_{2}$, and lactam $\left.\beta-\mathrm{CH}_{2}\right), 1.58$ and $1.56\left(2 \mathrm{x} \mathrm{d}, 3 \mathrm{H}, J=9.87 \mathrm{~Hz}, \alpha-\mathrm{CH}_{3}\right), 1.48$ and $1.46(2 \mathrm{x}$ s, 9H, $t$-butyl $\mathrm{CH}_{3}$ ). ${ }^{13} \mathrm{C}$ NMR $\delta$ (two rotamers present) 174.1 (C=O, lactam), 153.5 (C=O, Boc), 140.4 (ipso aromatic), 128.4 (meta), 127.6 (ortho), 127.1 (para), 80.0 and 79.4 (t-butyl $\mathrm{C}_{\mathrm{q}}$ ), 67.3 (spiro $\mathrm{C}_{\mathrm{q}}$ ), 49.6 and $49.2(\alpha-\mathrm{CH}), 48.1$ and 47.8 (pyrrolidine $\left.\alpha-\mathrm{CH}_{2}\right), 38.6$ and $37.9\left(\mathrm{CH}_{2}\right.$, lactam $\left.\gamma-\mathrm{CH}_{2}\right), 36.9$ and $36.6\left(\mathrm{CH}_{2}\right.$, pyrrolidine $\left.\gamma-\mathrm{CH}_{2}\right), 30.4$ and 29.9 (lactam $\left.\beta-\mathrm{CH}_{2}\right), 28.5$ and 28.4 (t-butyl $\left.\mathrm{CH}_{3}\right), 23.3$ and $22.4\left(\mathrm{CH}_{2}\right.$, pyrrolidine $\left.\beta-\mathrm{CH}_{2}\right), 15.6$ and $15.5\left(\alpha-\mathrm{CH}_{3}\right)$. Microanalysis: Found $\mathrm{C}$, 69.87; H, 8.49; N, 7.86. Calculated for $\mathrm{C}_{20} \mathrm{H}_{28} \mathrm{~N}_{2} \mathrm{O}_{3}: \mathrm{C}, 69.74 ; \mathrm{H}, 8.16 ; \mathrm{N}, 8.13$. 
12b was obtained as a white solid. $\mathrm{R}_{\mathrm{f}} 0.68$ (60\% ethyl acetate/hexane). Mp 128-132 ${ }^{\circ} \mathrm{C}$. IR $(\mathrm{KBr}) / \mathrm{cm}^{-1} 3032,2975,1700,1685,1360 .{ }^{1} \mathrm{H}$ NMR (two rotamers present) $\delta$ 7.45-7.22 (m, 5H, aromatic), 5.48 (q, 0.5H, $J=7.14 \mathrm{~Hz}, \alpha-\mathrm{CH}), 5.38$ (q, 0.5H, $J=$ $7.14 \mathrm{~Hz}, \alpha-\mathrm{CH}), 3.61-3.48\left(\mathrm{~m}, 2 \mathrm{H}\right.$, pyrrolidine $\left.\alpha-\mathrm{CH}_{2}\right), 3.19-3.03(\mathrm{~m}, 2 \mathrm{H}$, lactam $\gamma-$ $\left.\mathrm{CH}_{2}\right), 2.58-2.37\left(2 \mathrm{x} \mathrm{m}, 1 \mathrm{H}\right.$, lactam $\left.\beta-\mathrm{CH}_{2}\right), 2.17-1.76(\mathrm{~m}, 5 \mathrm{H}$, pyrrolidine $\beta$ - and $\gamma-$ $\mathrm{CH}_{2}$, and lactam $\left.\beta-\mathrm{CH}_{2}\right), 1.50$ and $1.48\left(2 \mathrm{x} \mathrm{d}, 3 \mathrm{H}, J=14.28 \mathrm{~Hz}, \alpha-\mathrm{CH}_{3}\right), 1.46$ and 1.26 (2 x s, 9H, $t$-butyl $\mathrm{CH}_{3}$ ). ${ }^{13} \mathrm{C} \mathrm{NMR}$ (two rotamers present) $\delta 174.4$ and 174.2 $(\mathrm{C}=\mathrm{O}$, lactam), 153.5 (C=O, Boc), 140.1 (ipso aromatic), 127.64 (meta), 127.61 (ortho), 127.5 (para), 80.3 and 79.5 (spiro $\mathrm{C}_{\mathrm{q}}$ ), 67.5 and 67.4 (t-butyl $\mathrm{C}_{\mathrm{q}}$ ), 50.9 and $49.5(\alpha-\mathrm{CH}), 48.6$ and $48.2\left(\mathrm{CH}_{2}\right.$, pyrrolidine $\left.\alpha-\mathrm{CH}_{2}\right), 38.9$ and $38.7\left(\mathrm{CH}_{2}\right.$, lactam $\gamma-$ $\left.\mathrm{CH}_{2}\right), 37.5$ and $37.1\left(\mathrm{CH}_{2}\right.$, pyrrolidine $\left.\gamma-\mathrm{CH}_{2}\right), 30.4$ and $30.1\left(\mathrm{CH}_{2}\right.$, lactam $\left.\beta-\mathrm{CH}_{2}\right)$, 28.8 and $28.5\left(\mathrm{CH}_{3},\left(t\right.\right.$-butyl $\left.\mathrm{CH}_{3}\right), 23.6$ and $22.6\left(\mathrm{CH}_{2}\right.$, pyrrolidine $\left.\beta-\mathrm{CH}_{2}\right), 16.6$ and $16.4\left(\mathrm{CH}_{3},\left(\alpha-\mathrm{CH}_{3}\right)\right.$. Microanalysis: Found C, 70.38; H, 8.65; N, 7.53. Calculated for $\mathrm{C}_{20} \mathrm{H}_{28} \mathrm{~N}_{2} \mathrm{O}_{3}$ : C, 69.74; H, 8.16; N, 8.13.

(5R) and (5S)-6-Oxo-7-((1'S)-phenylethyl-)-1,7-diaza-spiro[4.4]nonane-1carboxylic acid tert-butyl ester (12c and 12d).

Prepared by a similar method to the preparation of $\mathbf{1 2 a}$ and $\mathbf{1 2 b}$ using $(S)-(-)-1$ phenylethyl amine in $51 \%$ yield. 12c was obtained as a white solid. Analytical data were the same as 12b. Microanalysis: Found C, 69.68; H, 8.14; N, 8.05. Calculated for $\mathrm{C}_{20} \mathrm{H}_{28} \mathrm{~N}_{2} \mathrm{O}_{3}$ : C, 69.74; H, 8.16; N, 8.13.

12d was obtained as a white solid. Analytical data were the same as 12a. Microanalysis: Found C, 69.49; H, 8.14; N, 7.89. Calculated for $\mathrm{C}_{20} \mathrm{H}_{28} \mathrm{~N}_{2} \mathrm{O}_{3}$ : C, 69.74; H, 8.16; N, 8.13.

\section{(5S)-6-Oxo-7-((1'R)-phenylethyl-)-1,7-diaza-spiro[4.4]nonane (13a).}

To a stirred solution of $\mathbf{1 2 a}(0.270 \mathrm{~g}, 0.78 \mathrm{mmol})$ in DCM $(2.7 \mathrm{ml})$ was added TFA $(2.7 \mathrm{ml})$ and the resulting solution was stirred for $2 \mathrm{~h}$ at ambient temperature. The solution was basified to $\mathrm{pH} 10$ with aqueous $3 \mathrm{M} \mathrm{KOH}$ solution, and extracted with chloroform ( $2 \times 30 \mathrm{ml})$. The combined organic layers were washed with brine $(2 \times 20$ $\mathrm{ml})$, dried over $\mathrm{MgSO}_{4}$ and concentrated in vacuo giving a yellow oil (0.169 g, 89\%). $\mathrm{R}_{\mathrm{f}} 0.24$ (10\% methanol/ethyl acetate). $[\alpha]_{D}^{20}+9616.6$ (c $=0.0180$, methanol). IR (thin 
film) $/ \mathrm{cm}^{-1} 3329,2972,2876,1682 .{ }^{1} \mathrm{H}$ NMR $\delta$ 7.36-7.26 (m, 5H, aromatic), 5.50-5.46 (q, $1 \mathrm{H}, J=6.93 \mathrm{~Hz}, \alpha-\mathrm{CH}), 3.29-3.20\left(\mathrm{~m}, 2 \mathrm{H}\right.$, pyrrolidine $\left.\alpha-\mathrm{CH}_{2}\right), 2.98-2.90$ and 2.84-2.76 (m x 2, 2H, lactam $\gamma-\mathrm{CH}_{2}$ ), 2.06 (s (br.), 1H, N-H), 2.01-1.74 (m, 6H, pyrrolidine $\beta$ - and $\gamma-\mathrm{CH}_{2}$, and lactam $\left.\beta-\mathrm{CH}_{2}\right), 1.55\left(\mathrm{~d}, 3 \mathrm{H}, J=7.14 \mathrm{~Hz}, \alpha-\mathrm{CH}_{3}\right) .{ }^{13} \mathrm{C}$ NMR $\delta 176.74$ (C=O, lactam), 140.0 (ipso aromatic), 128.5 (meta), 127.5 (ortho), 126.9 (para), 67.9 (spiro $\mathrm{C}_{\mathrm{q}}$ ), $49.4(\alpha-\mathrm{CH}), 47.5$ (lactam $\gamma-\mathrm{CH}_{2}$ ), 39.0 (pyrrolidine $\alpha$ $\left.\mathrm{CH}_{2}\right), 35.2\left(\mathrm{CH}_{2}\right.$, pyrrolidine $\left.\gamma-\mathrm{CH}_{2}\right), 34.8$ (lactam $\left.\beta-\mathrm{CH}_{2}\right), 26.1$ (pyrrolidine $\gamma-\mathrm{CH}_{2}$ ), $16.0\left(\alpha-\mathrm{CH}_{3}\right)$.

(5R)-6-Oxo-7-((1'R)-phenylethyl-)-1,7-diaza-spiro[4.4]nonane (13b).

This was prepared from 12b, by the method used for 12a. $73 \%$ yield as a light yellow oil. $\mathrm{R}_{\mathrm{f}} 0.26$ (10\% methanol/ethyl acetate). $[\alpha]_{D}^{20}+13211.3^{\circ}(\mathrm{c}=0.0246$, methanol). IR (thin film) $/ \mathrm{cm}^{-1} 3484,2970,2876,1682 .{ }^{1} \mathrm{H}$ NMR $\delta$ 7.36-7.26 (m, 5H, aromatic), 5.46-5.39 (q, $1 \mathrm{H}, J=7.14 \mathrm{~Hz}, \alpha-\mathrm{CH}), 3.34-3.15\left(\mathrm{~m}, 2 \mathrm{H}\right.$, pyrrolidine $\left.\alpha-\mathrm{CH}_{2}\right), 3.08$ 2.94 (m x 2, 2H, lactam $\gamma-\mathrm{CH}_{2}$ ), 2.77 (s (br.), 1H, N-H), 2.04-1.73 (m, 6H, pyrrolidine $\beta$ - and $\gamma-\mathrm{CH}_{2}$, and lactam $\left.\beta-\mathrm{CH}_{2}\right), 1.55\left(\mathrm{~d}, 3 \mathrm{H}, J=7.14 \mathrm{~Hz}, \alpha-\mathrm{CH}_{3}\right) .{ }^{13} \mathrm{C}$ NMR $\delta$ $175.9(\mathrm{C}=\mathrm{O}$, lactam), 139.0 (ipso aromatic), 128.6 (meta), 127.5 (ortho), 126.9 (para), 68.1 (spiro $\mathrm{C}_{\mathrm{q}}$ ), $49.6(\mathrm{CH}, \alpha-\mathrm{CH}), 47.2$ (lactam $\gamma-\mathrm{CH}_{2}$ ), 39.1 (pyrrolidine $\alpha$ $\mathrm{CH}_{2}$ ), 35.1 (pyrrolidine $\left.\gamma-\mathrm{CH}_{2}\right), 34.2$ (lactam $\left.\beta-\mathrm{CH}_{2}\right), 25.7\left(\mathrm{CH}_{2}\right.$, pyrrolidine $\left.\gamma-\mathrm{CH}_{2}\right)$, $16.3\left(\mathrm{CH}_{3}, \alpha-\mathrm{CH}_{3}\right)$.

(5R)-6-Oxo-7-((1'S)-phenylethyl-)-1,7-diaza-spiro[4.4]nonane (13c).

This was prepared from 12c, by the method used for 12a. 76\% yield as a light yellow oil. Analytical data were the same as 13a.

(5S)-6-Oxo-7-((1'S)-phenylethyl-)-1,7-diaza-spiro[4.4]nonane (13d).

This was prepared from 12d, by the method used for 13a. 80\% yield as a light yellow oil. Analytical data were the same as $\mathbf{1 3 b}$.

(5S)-7-((1'R)-Phenylethyl-)-1,7-diaza-spiro[4.4]nonane (14a).

To a stirring solution of lithium aluminium hydride $1 \mathrm{M}$ solution in THF (14.8 ml, $14.8 \mathrm{mmol})$ in dry $\mathrm{THF}(5 \mathrm{ml})$ at $-20{ }^{\circ} \mathrm{C}$ under nitrogen, was added a $13 \mathbf{a}(0.179 \mathrm{~g}$, 
$0.74 \mathrm{mmol})$ in dry THF $(1 \mathrm{ml})$ and the solution was allowed to warm to ambient temperature and stirred for $48 \mathrm{~h}$. To the reaction mixture, saturated sodium chloride solution and $50 \%$ sodium hydroxide solution were added alternately (each time adding 3 drops), until no hydride was left (i.e. until the solution did not vigorously react). The solution was then filtered, washing the precipitate thoroughly with chloroform $(3 \times 20 \mathrm{ml})$. The combined washings were dried over $\mathrm{K}_{2} \mathrm{CO}_{3}$ and concentrated in vacuo giving a yellow oil, which was purified on preparative TLC on silica gel in $40 \%$ methanol/chloroform to give a pale yellow oil $(0.090 \mathrm{~g}, 53 \%)$. $\mathrm{R}_{\mathrm{f}}$ 0.12 (40\% methanol/chloroform). $[\alpha]_{D}^{20}+4736.8(\mathrm{c}=0.019$, methanol). IR (thin film) $/ \mathrm{cm}^{-1}$ 3354, 2970, 2776. [Note: Pyrrolidine ring derived from lactam is labelled pyrrolidine B and other is pyrrolidine A] ${ }^{1} \mathrm{H}$ NMR $\delta$ 7.34-7.21 (m, 5H, aromatic), 3.24 (q, $1 \mathrm{H}, J=6.6 \mathrm{~Hz}, \alpha-\mathrm{CH}), 3.01-2.88\left(\mathrm{~m}, 3 \mathrm{H}\right.$, pyrrolidine $\mathrm{B} \delta-\mathrm{CH}_{2}$ and pyrrolidine A $\left.\alpha-\mathrm{CH}_{2}\right), 2.62-2.54\left(\mathrm{~m}, 2 \mathrm{H}\right.$, pyrrolidine $\mathrm{B} \delta-\mathrm{CH}_{2}$ and pyrrolidine $\left.\mathrm{B} \alpha-\mathrm{CH}_{2}\right), 2.37(\mathrm{~d}$, $1 \mathrm{H}, J=9.33 \mathrm{~Hz}$, pyrrolidine B $\left.\alpha-\mathrm{CH}_{2}\right), 1.89-1.68\left(\mathrm{~m}, 6 \mathrm{H}\right.$, pyrrolidine $\mathrm{B} \gamma-\mathrm{CH}_{2}$, pyrrolidine A $\beta-\mathrm{CH}_{2}$ and pyrrolidine A $\left.\gamma-\mathrm{CH}_{2}\right), 1.35\left(\mathrm{~d}, 3 \mathrm{H}, J=6.6 \mathrm{~Hz}, \alpha-\mathrm{CH}_{3}\right) .{ }^{13} \mathrm{C}$ NMR $\delta 145.43$ (ipso aromatic), 128.2 (meta), 127.0 (ortho), 126.7 (para), 68.21 (spiro $\mathrm{C}_{\mathrm{q}}$ ), $65.5(\alpha-\mathrm{CH}), 64.8$ (pyrrolidine B $\alpha-\mathrm{CH}_{2}$ ), 52.0 (pyrrolidine B $\delta-\mathrm{CH}_{2}$ ), 45.2 (pyrrolidine A $\alpha-\mathrm{CH}_{2}$ ), 38.2 (pyrrolidine A $\gamma-\mathrm{CH}_{2}$ ), 37.8 (pyrrolidine $\mathrm{B} \gamma-\mathrm{CH}_{2}$ ), 24.7 (pyrrolidine A $\left.\beta-\mathrm{CH}_{2}\right), 23.6\left(\mathrm{CH}_{3}, \alpha-\mathrm{CH}_{3}\right)$. Mass spectrum $m / z[\mathrm{M}+\mathrm{H}] 231.1857$ (calculated for $\mathrm{C}_{15} \mathrm{H}_{23} \mathrm{~N}_{2}$ 231.1861).

(5R)-7-((1'R)-Phenylethyl-)-1,7-diaza-spiro[4.4]nonane (14b).

This was prepared from $\mathbf{1 3 b}$, by the method used for $14 \mathbf{a}$. $46 \%$ yield as a pale yellow oil. $R_{\mathrm{f}} 0.12$ (40\% methanol/chloroform). $[\alpha]_{D}^{20}+3928.5$ (c = 0.021, methanol). IR (thin film) $/ \mathrm{cm}^{-1} 3359,2970,2776 .{ }^{1} \mathrm{H}$ NMR $\delta$ 7.35-7.21 (m, 5H, aromatic), 3.27 (q, $1 \mathrm{H}, J=6.6 \mathrm{~Hz}, \alpha-\mathrm{CH}), 3.03-2.84\left(\mathrm{~m}, 3 \mathrm{H}\right.$, pyrrolidineB $\delta-\mathrm{CH}_{2}$ and pyrrolidine $\mathrm{A} \alpha$ $\left.\mathrm{CH}_{2}\right), 2.52\left(\mathrm{~d}, 1 \mathrm{H}, J=9.5 \mathrm{~Hz}\right.$, pyrrolidineB $\left.\alpha-\mathrm{CH}_{2}\right), 2.40(\mathrm{~d}, 1 \mathrm{H}, J=9.5 \mathrm{~Hz}$, pyrrolidineB $\left.\alpha-\mathrm{CH}_{2}\right), 2.4-2.36\left(\mathrm{~m}, 1 \mathrm{H}\right.$, pyrrolidineB $\left.\delta-\mathrm{CH}_{2}\right), 1.94-1.74(\mathrm{~m}, 6 \mathrm{H}$, pyrrolidineB $\gamma-\mathrm{CH}_{2}$, pyrrolidine $\mathrm{A} \beta-\mathrm{CH}_{2}$ and pyrrolidine $\left.\mathrm{A} \gamma-\mathrm{CH}_{2}\right), 1.35(\mathrm{~d}, 3 \mathrm{H}, J=$ $6.6 \mathrm{~Hz}, \alpha-\mathrm{CH}_{3}$ ). ${ }^{13} \mathrm{C} \mathrm{NMR} \delta 145.35$ (ipso aromatic), 128.2 (meta), 127.1 (ortho), 126.7 (para), 68.4 (spiro $\mathrm{C}_{\mathrm{q}}$ ), $65.3(\alpha-\mathrm{CH}), 64.3 \quad$ (pyrrolidineB $\alpha-\mathrm{CH}_{2}$ ), 51.7 (pyrrolidineB $\delta-\mathrm{CH}_{2}$ ), 45.0 (pyrrolidineA $\alpha-\mathrm{CH}_{2}$ ), 37.9 (pyrrolidineA $\gamma-\mathrm{CH}_{2}$ ), 37.1 
(pyrrolidineB $\gamma-\mathrm{CH}_{2}$ ), 24.3 (pyrrolidineA $\left.\beta-\mathrm{CH}_{2}\right), 22.8\left(\alpha-\mathrm{CH}_{3}\right)$. Mass spectrum $\mathrm{m} / \mathrm{z}$ $[\mathrm{M}+\mathrm{H}] 231.1858$ (calculated for $\mathrm{C}_{15} \mathrm{H}_{23} \mathrm{~N}_{2} 231.1861$ ).

\section{(5R)-7-((1'S)-Phenylethyl-)-1,7-diaza-spiro[4.4]nonane (14c).}

This was prepared from 13c, by the method used for $14 \mathbf{a}$. $48 \%$ yield as a pale yellow oil. Analytical data were the same as 14a. Mass spectrum $m / z[\mathrm{M}+\mathrm{H}] 231.1864$ (calculated for $\mathrm{C}_{15} \mathrm{H}_{23} \mathrm{~N}_{2} 231.1861$ ).

\section{(5S)-7-((1'S)-Phenylethyl-)-1,7-diaza-spiro[4.4]nonane (14d).}

This was prepared from 13d, by the method used for 14a. $43 \%$ yield as a pale yellow oil. Analytical data was the same as 14b. Mass spectrum $\mathrm{m} / \mathrm{z}$ [ $\mathrm{M}+\mathrm{H}] 231.1871$ (calculated for $\mathrm{C}_{15} \mathrm{H}_{23} \mathrm{~N}_{2} 231.1861$ ).

\section{X-Ray Crystallography:}

Suitable crystals of $\mathbf{1 5 a}$ and $\mathbf{1 5 b}$ for X-ray study were obtained from ethanol solutions. The data were collected at 150(2)K on a Bruker APEX CCD diffractometer. The structure was solved by direct methods and refined on $\mathrm{F}^{2}$ using all the reflections. ${ }^{19}$ All the non-hydrogen atoms were refined using anisotropic atomic displacement parameters and hydrogen atoms were inserted at calculated positions using a riding model.

Compound 15a. Crystal data: $\mathrm{C}_{15} \mathrm{H}_{22} \mathrm{Cl}_{2} \mathrm{~N}_{2} \mathrm{Zn}, M=366.62$, triclinic, $a=7.288(3), b$ $=10.862(5), c=11.169(5) \AA, \alpha=90.304(6)^{\circ}, \beta=103.671(5)^{\circ}, \gamma=95.005(6)^{\circ}, U=$ 855.5(7) $\AA^{3}$, space group $P 1, Z=2, \mu(\mathrm{Mo}-\mathrm{K} \alpha)=1.740 \mathrm{~mm}^{-1} .6662$ data $(5905$ unique, $\left.R_{\text {int }}=0.0261\right)$ were measured in the range $1.88<\theta<25.99^{\circ} . R_{1}(I>2 \sigma(I))=$ 0.0376 and $w R_{2}$ (all data) $=0.0986$. Goodness of fit on $F^{2}=1.004$. CCDC No. 641381 .

\section{Molecular Modelling:}

The energy of the conformations of $\mathbf{1 2 a}$ and $\mathbf{1 2 b}$ were minimised using the $\mathrm{MM}^{+}$ molecular mechanics force field in HYPERCHEM 7.5.

\section{Supplementary Data.}


Crystallographic data for 15a has been deposited with the Cambridge Crystallographic Data Centre. Copies of this information may be obtained free of charge from deposit@ccdc.cam.ac.uk or www: http://www.ccdc.cam.ac.uk

\section{Acknowledgements.}

We thank Dr Brian Murray for help with NMR spectroscopy and useful discussions. We are grateful to Kuldip Singh for access to the Apex diffractometer at the University of Leicester, UK. We are grateful to Strand III of the Irish Government's National Development Plan (2000-2006) Technological Sector Research Program, through the Council of Directors of the Institutes of Technology, for funding for SK (Grant CRS/01/TA02).

\section{References.}

1. Lucet, D.; Le Gall, T.; Mioskowski, C. Angew. Chem. Int. Ed. 1998, 37, 2581-2627.

2. Bennani, Y. L.; Hanessian, S. Chem. Rev. 1997, 97, 3161-3197.

3. Samanen, J.; Wilson, G.; Smith, P.; Lee, C.-P.; Bondinell, W.; Ku, T.; Rhodes, G.; Nichols, A. J. Pharm. Pharmacol. 1996, 48, 119-135.

4. For example, Burgess, K.; Ho, K-K.; Pettitt, B., J. Am. Chem. Soc. 1995, $117,54-65$.

5. Schultz, T. Synlett 2003, 901-902 and references cited therein.

6. Sannigrahi, M. Tetrahedron 1999, 55, 9007-9071.

7. (a) Freidinger, R.; Veber, D.; Perlow, D.; Brooks, J.; Saperstein, R. Science, 1980, 210, 656-658. (b) Freidinger, R.; Perlow, D.; Veber, D. J. Org. Chem., 1982, 47, 104-109.

8. A number of examples are given and the list is far from exhaustive: (a) Ref. 7b. (b) Mueller, R.; Revesz, L. Tetrahedron Lett. 1994, 35, 40914092. (c) Reddy, P.; Hsiang, B.; Latifi, T.; Hill, M.; Woodward, K.; Rothman, S.; Ferrendelli, J.; Covey, D. J. Med. Chem. 1996, 39, 18981906. (d) Batey, R., Mackay, D. Tetrahedron Lett. 2000, 41, 9935-9938. (e) Vitry, C.; Vasse, J-L., Dupas, G.; Levacher.; Queguiner, G.; Bourguignon, J. Tetrahedron 2001, 57, 3087-3098. (f) Nagata, T.; Nishida, 
A.; Nakagawa, M. Tetrahedron Lett. 2001, 42, 8345-8349. (g) Herrero, S.; Garcia-Lopez, M.; Latorre, M.; Cenarruzabeitia, E.; Del Rio, J.; Herranz, R. J. Org. Chem. 2002, 67, 3866-3873.

9. Seebach, D.; Boes, M.; Naef, R.; Schweizer, W. J. Am. Chem. Soc. 1983, 105, 5390-5398.

10. (a) Castelhano, A. Witter, D. Patent No. US6638941B1 2003; Chem. Abstr. 2003, 139, 345905. (b) Montserrat Fernandez, M.; Diez, A., Rubiralta, M.; Montenegro, E.; Casamitjana, N. J. Org. Chem. 2002, 67, 7587-7599. (c) Millet, R.; Goosens, L.; Bertrand-Caumont, K.; Goosens, J.-F.; Houssin, R.; Henichart, J.-P. J. Pharm. Pharmacol. 2001, 53, 929934. (d) Millet, R.; Goosens, L.; Bertrand-Caumont, K.; Houssin, R.; Rigo, B.; Goosens, J.-F.; Henichart, J.-P. Lett. Peptide Sci. 2001, 7, 269-279. (e) Khalil, E.; Ojala, W.; Pradhan, A.; Nair, V.; Gleason, W.; Mishra, R.; Johnson, R. J. Med. Chem. 1999, 42, 628-637. (f) Witter, D.; Famiglietti, S.; Cambier, J.; Castelhano, A. Bioorg. Med. Chem. Lett. 1998, 8, 31373142. (g) Genin, M.; Gleason, W.; Johnson, R. J. Org. Chem. 1993, 58, 860-866. (h) Ward, P.; Ewan, G.; Jordan, C.; Ireland, S.; Hagan, R.; Brown, J. J. Med. Chem. 1990, 33, 1848-1851.

11. (a) Genin, M.; Ojala, W.; Gleason, W.; Johnson, R. J. Org. Chem. 1993, 58, 2334-2337. (b) Ref. 10f. (c) Hinds, M.; Welsh, J.; Brennand, D.; Fisher, J.; Glennie, M.; Richards, N.; Turner, D.; Robinson, J. J. Med. Chem. 1991, 34, 1777-1789.

12. Ács, M.; Fogassy, E.; Faigl, F. Tetrahedron 1985, 41, 2465-2470.

13. Kelleher, F.; Kelly, S. Tetrahedron Lett. 2006, 47, 3005-3008.

14. Confalone, P.; Huie, E.; Ko, S.; Cole, G. J. Org. Chem. 1988, 53, 482-487.

15. Kelleher, F.; Kelly, S. Tetrahedron Lett. 2006, 47, 5247-5250.

16. Auberson, Y.; Glatthar, R.; Salter, R.; Simic, O.; Tintelnot-Blomley, M. Patent No. WO2005/035535 A1. 2005; Chem. Abstr. 2005, 142, 411343.

17. HYPERCHEM Release 7.5, 2003, Hypercube Inc., Gainesville, Florida, USA.

18. Mukaiyama, T. Aldrichimica Acta 1996, 29, 59-76.

19. G.M. Sheldrick, SHELXTL Version 6.12, Bruker AXS, Madison WI, USA, 2001. 


\section{Captions}

Figure 1. Ethylenediamine 1; trans-1,2-Diaminocyclohexane 2; (-)-Sparteine 3 and 1,7-Diaza-spiro[4.5]decane 4.

Figure 2: Cyclisation methods for proline-derived spirolactams. ${ }^{8,10,11}$

Figure 3. Energy minimised conformations of $\mathbf{1 2 a}(S, R)$ and $\mathbf{1 2 b}(R, R) .{ }^{17}$

Figure 4. X-ray crystal structure of spirodiamine- $\mathrm{ZnCl}_{2}$ complex $\mathbf{1 5 a}$.

Figure 5. Mukaiyama's diamines 16, complexed to $\mathrm{Sn}(\mathrm{OTf})_{2}{ }^{17}$ and $\mathrm{ZnCl}_{2}$.

\section{Figures}
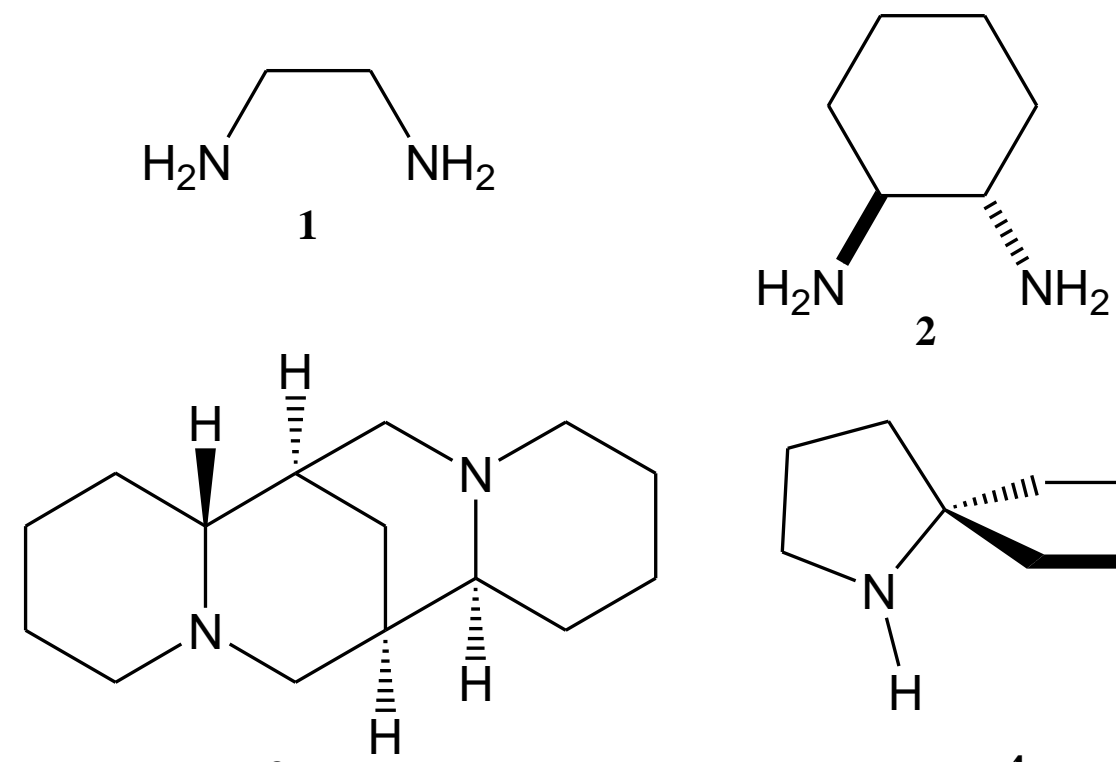

3

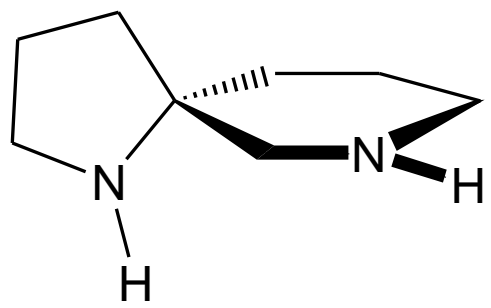

4

Figure 1. Ethylenediamine 1; trans-1,2-Diaminocyclohexane 2; (-)-Sparteine 3 and 1,7-Diaza-spiro[4.5]decane 4. 
(i)<smiles>CPCCCC1(C(=O)O)CCCN1C(=O)OCc1ccccc1</smiles><smiles>[2H]N1CCC2(CCCN2C(=O)OC(C)(C)C)C1=O</smiles>

(ii)

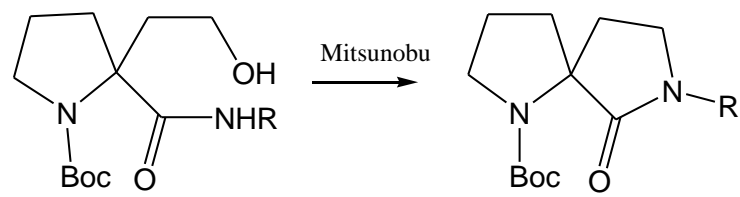

(iii)

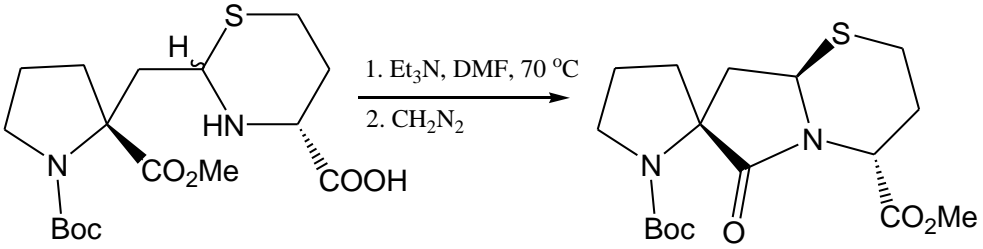

Figure 2: Cyclisation methods for proline-derived spirolactams. ${ }^{8,10,11}$

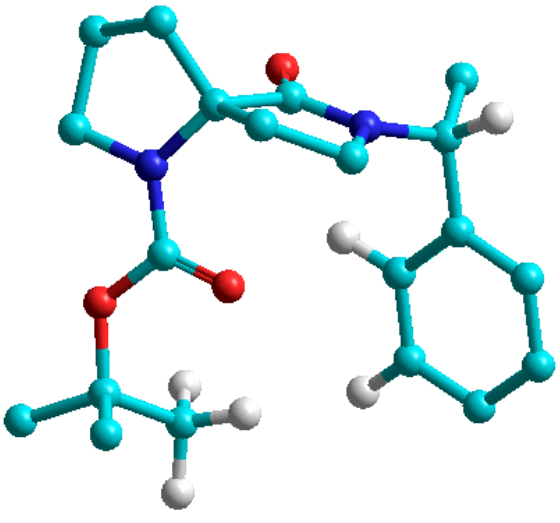

$S, R$-Diastereoisomer

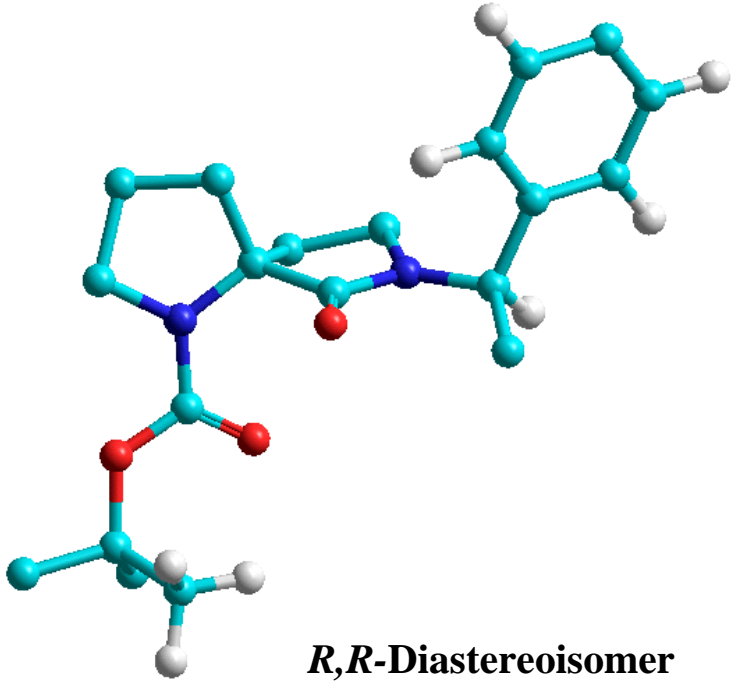

$\boldsymbol{R}, \boldsymbol{R}$-Diastereoisomer

Figure 3. Energy minimised conformations of $\mathbf{1 2 a}(S, R)$ and $\mathbf{1 2 b}(R, R) .{ }^{17}$ 


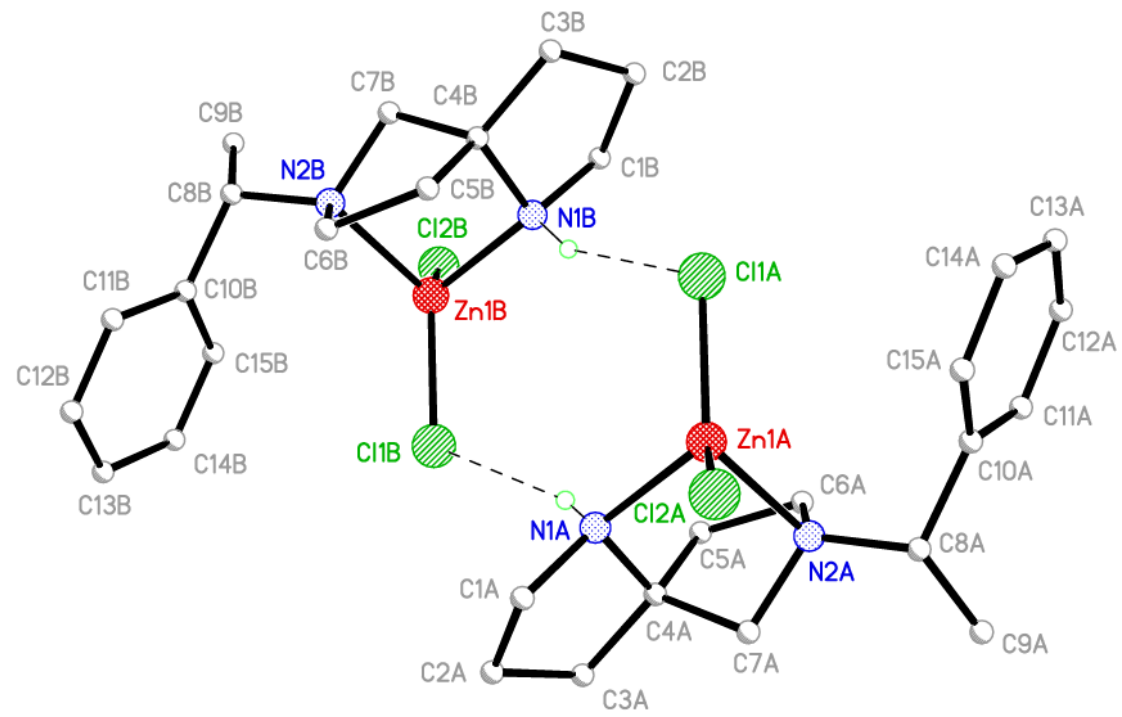

Figure 4. X-ray crystal structure of spirodiamine- $\mathrm{ZnCl}_{2}$ complex $\mathbf{1 5 a}$.<smiles>[R]N([R3])C[C@@H]1CCCN1[R7]</smiles>

16

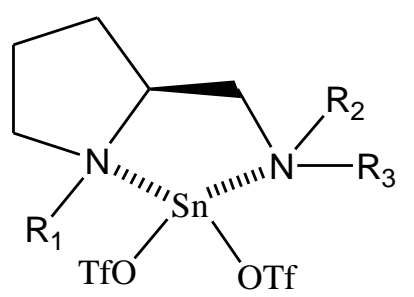

TfO OTf

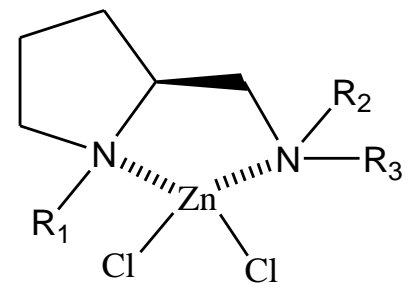

Figure 5. Mukaiyama's diamines 16, complexed to $\mathrm{Sn}(\mathrm{OTf})_{2}{ }^{17}$ and $\mathrm{ZnCl}_{2}$. 


\section{Schemes}

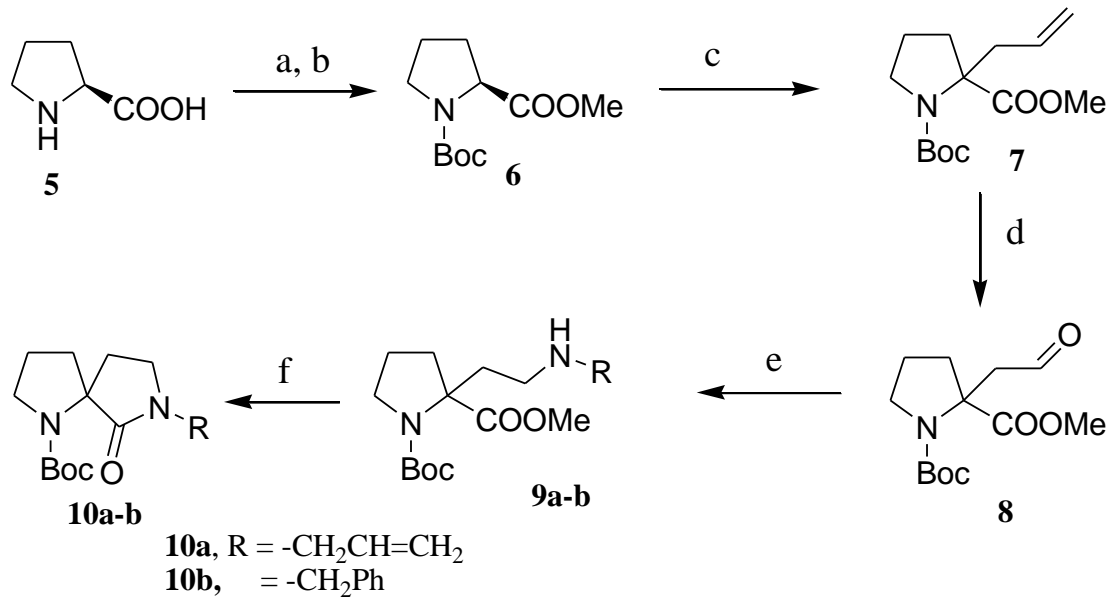

Scheme 1: Reagents and conditions; (a) $\mathrm{SOCl}_{2}, \mathrm{MeOH}$, reflux, 94\%; (b) (Boc) ${ }_{2} \mathrm{O}, \mathrm{DMAP}, \mathrm{Et}_{3} \mathrm{~N}, \mathrm{DCM}, \mathrm{rt}, 74 \%$;

(c) i) LiHMDS, THF, $-78{ }^{\circ} \mathrm{C}$, ii) allyl bromide, rt, $80 \%$; (d) $\mathrm{OsO}_{4} / \mathrm{NaIO}_{4}, \mathrm{THF}: \mathrm{H}_{2} \mathrm{O}(4: 1)$, rt, $74 \%$;

(e) i) $\mathrm{RNH}_{2}, \mathrm{EtOH}$, ii) $\mathrm{NaBH}_{4}$, rt; (f) Toluene, reflux, 60-88\%.

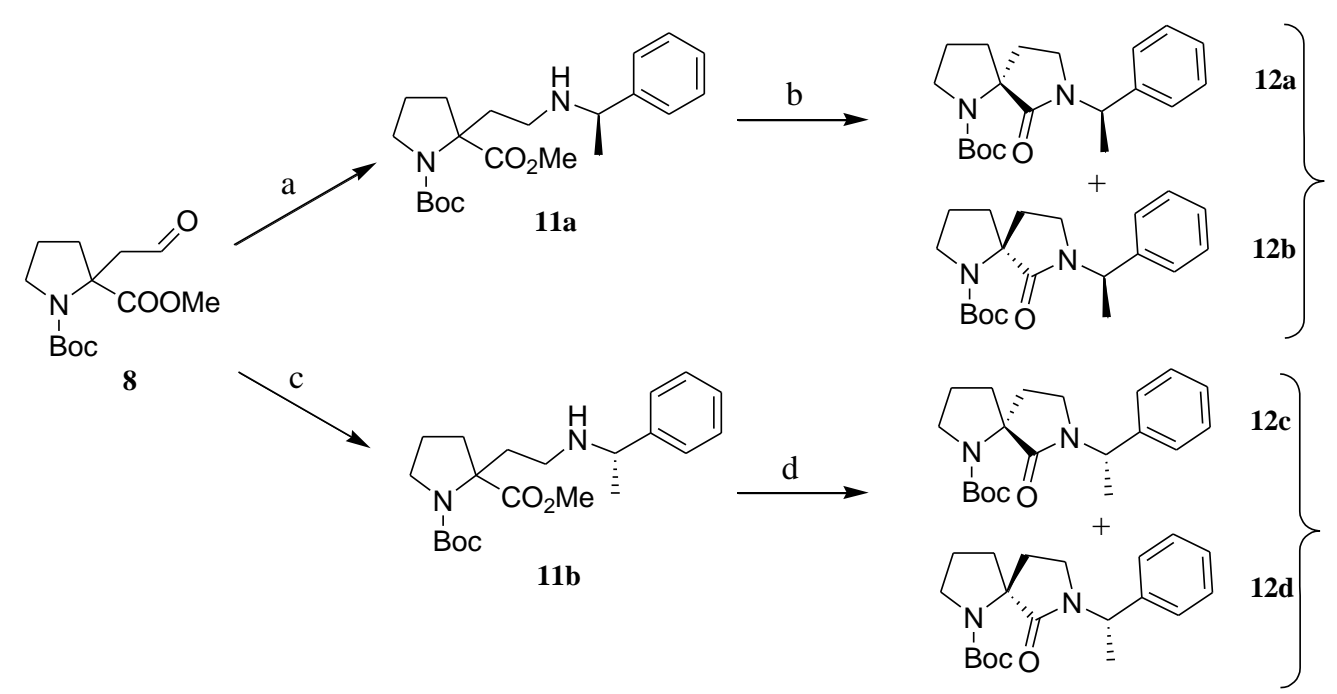

Scheme 2: Reagents and conditions; (a) i) (R)-1-phenylethylamine, $\mathrm{MgSO}_{4}, \mathrm{MeOH}$, ii) $\mathrm{NaBH}_{4}$, rt; (b) $\mathrm{NaNH}_{2}$ in toluene, reflux, $30 \%$ from 4; (c) i) (S)-1-phenylethylamine, $\mathrm{MgSO}_{4}, \mathrm{MeOH}$, ii) $\mathrm{NaBH}_{4}$, rt; (d) $\mathrm{NaNH}_{2}$ in toluene, reflux, $51 \%$ from 4. 
<smiles>CC(C)C(=O)N1CCC[C@]12CCNC2C(C)c1ccccc1</smiles><smiles>CC(c1ccccc1)N1CCC2(CCCN2C(=O)O)C1=O</smiles><smiles>[Z10]C(C)CN1CCC[C@]12CCCN2[C@H](C)c1ccccc1</smiles><smiles>CC(C)C(=O)N1CCCC12CCN(C(=O)OC(C)(C)C)C2=O</smiles>

Scheme 3: Reagents and conditions; (a) i) 50\% TFA in DCM, ii) 3 M KOH; (b) $\mathrm{LiAlH}_{4}$, THF, rt.

\section{Tables}

Table 1. Selected bond lengths $(\AA)$ and angles $\left(^{\circ}\right)$ for $\mathbf{1 5 a}$.

\begin{tabular}{|l|l|l|l|}
\hline Bond & Bond lengths & Angle & Bond Angles \\
\hline $\mathrm{Zn}(1 \mathrm{~A})-\mathrm{N}(1 \mathrm{~A})$ & $2.067(5)$ & $\mathrm{N}(1 \mathrm{~A})-\mathrm{Zn}(1 \mathrm{~A})-\mathrm{N}(2 \mathrm{~A})$ & $84.4(2)$ \\
\hline $\mathrm{Zn}(1 \mathrm{~A})-\mathrm{N}(2 \mathrm{~A})$ & $2.1046)$ & $\mathrm{N}(1 \mathrm{~A})-\mathrm{Zn}(1 \mathrm{~A})-\mathrm{Cl}(1 \mathrm{~A})$ & $113.11(16)$ \\
\hline $\mathrm{Zn}(1 \mathrm{~A})-\mathrm{Cl}(1 \mathrm{~A})$ & $2.213(2)$ & $\mathrm{N}(2 \mathrm{~A})-\mathrm{Zn}(1 \mathrm{~A})-\mathrm{Cl}(1 \mathrm{~A})$ & $117.00(16)$ \\
\hline $\mathrm{Zn}(1 \mathrm{~A})-\mathrm{Cl}(2 \mathrm{~A})$ & $2.2191(18)$ & $\mathrm{N}(1 \mathrm{~A})-\mathrm{Zn}(1 \mathrm{~A})-\mathrm{Cl}(2 \mathrm{~A})$ & $108.42(17)$ \\
\hline $\mathrm{Zn}(1 \mathrm{~B})-\mathrm{N}(1 \mathrm{~B})$ & $2.049(5)$ & $\mathrm{N}(2 \mathrm{~A})-\mathrm{Zn}(1 \mathrm{~A})-\mathrm{Cl}(2 \mathrm{~A})$ & $107.20(16)$ \\
\hline $\mathrm{Zn}(1 \mathrm{~B})-\mathrm{N}(2 \mathrm{~B})$ & $2.117(5)$ & $\mathrm{Cl}(1 \mathrm{~A})-\mathrm{Zn}(1 \mathrm{~A})-\mathrm{Cl}(2 \mathrm{~A})$ & $120.71(7)$ \\
\hline $\mathrm{Zn}(1 \mathrm{~B})-\mathrm{Cl}(2 \mathrm{~B})$ & $2.2118(19)$ & $\mathrm{N}(1 \mathrm{~B})-\mathrm{Zn}(1 \mathrm{~B})-\mathrm{N}(2 \mathrm{~B})$ & $84.4(2)$ \\
\hline $\mathrm{Zn}(1 \mathrm{~B})-\mathrm{Cl}(1 \mathrm{~B})$ & $2.213(2)$ & $\mathrm{N}(1 \mathrm{~B})-\mathrm{Zn}(1 \mathrm{~B})-\mathrm{Cl}(2 \mathrm{~B})$ & $109.46(16)$ \\
\hline & & $\mathrm{N}(2 \mathrm{~B})-\mathrm{Zn}(1 \mathrm{~B})-\mathrm{Cl}(2 \mathrm{~B})$ & $111.39(17)$ \\
\hline & & $\mathrm{N}(1 \mathrm{~B})-\mathrm{Zn}(1 \mathrm{~B})-\mathrm{Cl}(1 \mathrm{~B})$ & $110.69(17)$ \\
\hline & & $\mathrm{N}(2 \mathrm{~B})-\mathrm{Zn}(1 \mathrm{~B})-\mathrm{Cl}(1 \mathrm{~B})$ & $116.31(17)$ \\
\hline & & $\mathrm{Cl}(2 \mathrm{~B})-\mathrm{Zn}(1 \mathrm{~B})-\mathrm{Cl}(1 \mathrm{~B})$ & $119.11(7)$ \\
\hline
\end{tabular}

